\title{
Roles of ephrinB ligands and EphB receptors in cardiovascular development: demarcation of arterial/venous domains, vascular morphogenesis, and sprouting angiogenesis
}

\author{
Ralf H. Adams, ${ }^{1}$ George A. Wilkinson, ${ }^{1}$ Cornelia Weiss, ${ }^{2}$ Francesca Diella, ${ }^{1}$ Nicholas W. Gale, ${ }^{3}$ \\ Urban Deutsch, $^{2}$ Werner Risau, ${ }^{2,4}$ and Rüdiger Klein ${ }^{1,5}$ \\ ${ }^{1}$ European Molecular Biology Laboratory, D-69117 Heidelberg, Germany; ${ }^{2}$ Max-Planck-Institute for Physiological \\ and Clinical Research, W.G. Kerckhoff Institute, 61231 Bad Nauheim, Germany; ${ }^{3}$ Regeneron Pharmaceuticals, Inc., \\ Tarrytown, New York 10591 USA
}

Eph receptor tyrosine kinases and their cell-surface-bound ligands, the ephrins, regulate axon guidance and bundling in the developing brain, control cell migration and adhesion, and help patterning the embryo. Here we report that two ephrinB ligands and three EphB receptors are expressed in and regulate the formation of the vascular network. Mice lacking ephrinB2 and a proportion of double mutants deficient in EphB2 and EphB3 receptor signaling die in utero before embryonic day 11.5 (E11.5) because of defects in the remodeling of the embryonic vascular system. Our phenotypic analysis suggests complex interactions and multiple functions of Eph receptors and ephrins in the embryonic vasculature. Interaction between ephrinB2 on arteries and its EphB receptors on veins suggests a role in defining boundaries between arterial and venous domains. Expression of ephrinB1 by arterial and venous endothelial cells and EphB3 by veins and some arteries indicates that endothelial cell-to-cell interactions between ephrins and Eph receptors are not restricted to the border between arteries and veins. Furthermore, expression of ephrinB2 and EphB2 in mesenchyme adjacent to vessels and vascular defects in $e p h B 2 / e p h B 3$ double mutants indicate a requirement for ephrin-Eph signaling between endothelial cells and surrounding mesenchymal cells. Finally, ephrinB ligands induce capillary sprouting in vitro with a similar efficiency as angiopoietin-1 (Ang1) and vascular endothelial growth factor (VEGF), demonstrating a stimulatory role of ephrins in the remodeling of the developing vascular system.

[Key Words: Angiogenesis; ephrins; Eph; receptor tyrosine kinase; vasculogenesis]

Received August 7, 1998; revised version accepted December 9, 1998.

The family of Eph receptor tyrosine kinases and their ephrin ligands play important roles in a variety of processes during embryonic development of mammals, lower vertebrates, and invertebrates such as Caenorhabditis elegans. They regulate topographic map formation in the retinotectal/retinocollicular system /Cheng et al. 1995; Drescher et al. 1995; Nakamoto et al. 1996; Frisen et al. 1998) and play essential roles in the formation and fasciculation of brain commissures (Henkemeyer et al. 1996; Orioli et al. 1996; Park et al. 1997). They have additional important functions in patterning of embryonic structures of the brain (Xu et al. 1995, 1996) and somites (Durbin et al. 1998). Ephrins control migration of neural crest cells into branchial arches and somites

\footnotetext{
${ }^{4}$ In memoriam: Werner Risau (Dec. 18, 1953-Dec. 13, 1998). ${ }^{5}$ Corresponding author.

E-MAIL klein@embl-heidelberg.de; FAX 49-6221-387 516 or 306.
}

(Krull et al. 1997; Smith et al. 1997; Wang and Anderson 1997). In these systems, ephrin-Eph interactions are thought to be mainly repulsive, that is, navigating growth cones or migrating cells expressing Eph receptors would turn away from cells expressing the corresponding ephrin ligand (Drescher et al. 1995; Nakamoto et al. 1996; Brennan et al. 1997; Krull et al. 1997; Wang and Anderson 1997). Repulsive interactions and complementary expression patterns suggest that ephrins and Eph receptors define spatial boundaries in the developing embryo (Gale et al. 1996).

The ephrin-Eph system functions in cell-to-cell rather than long range communications, because Eph receptors and all known ephrin ligands are attached to the plasma membrane (Davis et al. 1994; Orioli and Klein 1997). Ephrins can be divided into two subclasses: EphrinA ligands (ephrinA1-A5) are tethered to the cell surface via a glycosylphophatidylinositol (GPI)-anchor, whereas eph- 
rinB ligands (ephrinB1-B3) are inserted into the plasma membrane via a transmembrane region followed by a conserved cytoplasmic domain. This subdivision also matches the binding preferences of ephrinA and ephrinB molecules for the corresponding EphA or EphB receptor subfamilies, respectively, whereas within these subfamilies, interactions are highly promiscuous (Brambilla et al. 1995; Gale et al. 1996). Unlike soluble ligands for other receptor tyrosine kinases, ephrin molecules appear to be presented in a clustered state to acquire high stimulating activation towards their cognate Eph receptors (Davis et al. 1994). The state of aggregation could perhaps determine differential signaling responses of the Eph receptor (Stein et al. 1998) and ephrin-expressing cells may elicit different responses in Eph receptor-expressing neighbors depending on their degree of ligand clustering. With their highly conserved cytoplasmic domains, transmembrane ephrinB molecules resemble membrane receptors. Accumulating evidence points to an active signaling role for ephrinB molecules, resulting in reverse or-in combination with their ligand function-bidirectional signal transduction (Brückner and Klein 1998).

Evidence from an in vivo angiogenesis assay and in vitro studies suggested roles for ephrins and Eph receptors in the formation of blood vessels. EphrinA1 has in vivo angiogenic properties during inflammatory angiogenesis induced by tumor necrosis factor $\alpha$ (Pandey et al. 1995). Clustered ephrinB1 promotes endothelial capillary-like assembly and cell attachment in vitro (Stein et al. 1998). During embryonic development, the first step of blood vessel formation involves the differentiation of primitive mesodermal cells into vascular endothelial cells, which ultimately will line the internal surfaces of all vessels. Two processes can be distinguished. Vasculogenesis defines the formation of tubular structures from a dispersed population of endothelial cell precursors into a rather homogeneous honeycomb-like primary capillary network, the so-called primary capillary plexus of the embryo and extra-embryonic structures such as the yolk sac (Risau and Flamme 1995). Vasculogenesis also results in the formation of the primordia of the heart and large trunk vessels, such as the dorsal aorta and the cardinal veins. In a second process, termed angiogenesis, the primary vascular network is remodeled into a hierarchical network of small and large vessels through sprouting of new vessels, remodeling, and splitting of existing vessels. Moreover, avascular tissues such as the neuroepithelium are vascularized by sprouting of new capillaries. Angiogenesis is a complex process involving endothelial cell proliferation, chemotactic migration, and functional maturation (Risau 1997).

Recent studies have identified several receptor tyrosine kinases expressed on endothelial cells and their ligands as key regulators of vascular development during embryogenesis. Vascular endothelial growth factor (VEGF) and its tyrosine kinase receptor VEGF-R1/Flk-1 are essential for vasculogenesis and endothelial cell differentiation, whereas the VEGF-R2/Flt receptor is critically required for the organization of the embryonic vas- culature (Fong et al. 1995; Shalaby et al. 1995, 1997; Carmeliet et al. 1996; Ferrara et al. 1996). Angiopoietin-1 (Ang-1) and its tyrosine kinase receptor Tie-2/Tek are important regulators of angiogenesis and heart development, whereas Tie-1 receptors are important for blood vessel integrity (Dumont et al. 1994; Puri et al. 1995; Sato et al. 1995; Suri et al. 1996). Recently, ephrinB2 has been shown to be required for the remodeling of the embryonic vascular system (Wang et al. 1998). Because of its exclusive expression on arteries and the complementary expression of one of its cognate receptors, EphB4, on veins, it was suggested that ephrinB2 acts both as a ligand and as a receptor for EphB4 and that reciprocal, possibly repulsive signaling between these two types of vessels is crucial for angiogenic remodeling during the maturation of the vascular network (Wang et al. 1998; Yancopoulos et al. 1998).

In this report we implicate additional Eph receptors and ephrins in vascular development, thus indicating a much greater level of complexity in ephrin-Eph interactions. In contrast to Wang et al. (1998), we find that the ligand ephrinB1 is coexpressed with ephrinB2 in arteries, that ephrinB1 and EphB3 are coexpressed with EphB4 in venous endothelial cells, and that EphB3 is expressed by some arteries. Our findings therefore suggest that cellto-cell interactions between ephrins and Eph receptors are not restricted to the border between arteries and veins, but occur and are required throughout most of the embryonic vasculature. Consistent with our expression data, we show that double-mutant mice deficient in both EphB2 and EphB3 receptor signaling have a partially penetrant phenotype that resembles much of the ephrinB2 $2^{-/-}$phenotype. Prominent expression of ephrinB2 and EphB2 in mesenchymal cells adjacent to endothelial cells further indicates that ephrins and Eph receptors regulate and are required for interactions between endothelial and mesenchymal cells. Finally, we demonstrate in vitro capillary sprout-inducing activity for both ephrinB1 and ephrinB2, describing a stimulatory cellular response for these ligands during angiogenic remodeling.

\section{Results}

Coexpression of multiple ephrins and Eph receptors in yolk sac and embryonic blood vessels

Wang et al. (1998) recently generated an ephrinB2/taulac $Z$ allele to demonstrate ephrinB2 expression specifically in arteries and absent on veins. Conversely, in situ hybridization analysis indicated exclusive expression of EphB4 on veins. No other Eph receptor or ephrin ligand was detected on blood vessels. Our own expression analysis, however, indicates the presence of additional ephrinB molecules and EphB receptors in blood vessels. Although immunostainings for ephrinB2 showed strong expression on arteries (Fig. 1A) and barely detectable expression on veins (Fig. 1B), staining with the EphB3 receptor ectodomain protein probe fused to alkaline phosphatase (EphB3-AP), which binds to several ephrinBs, 

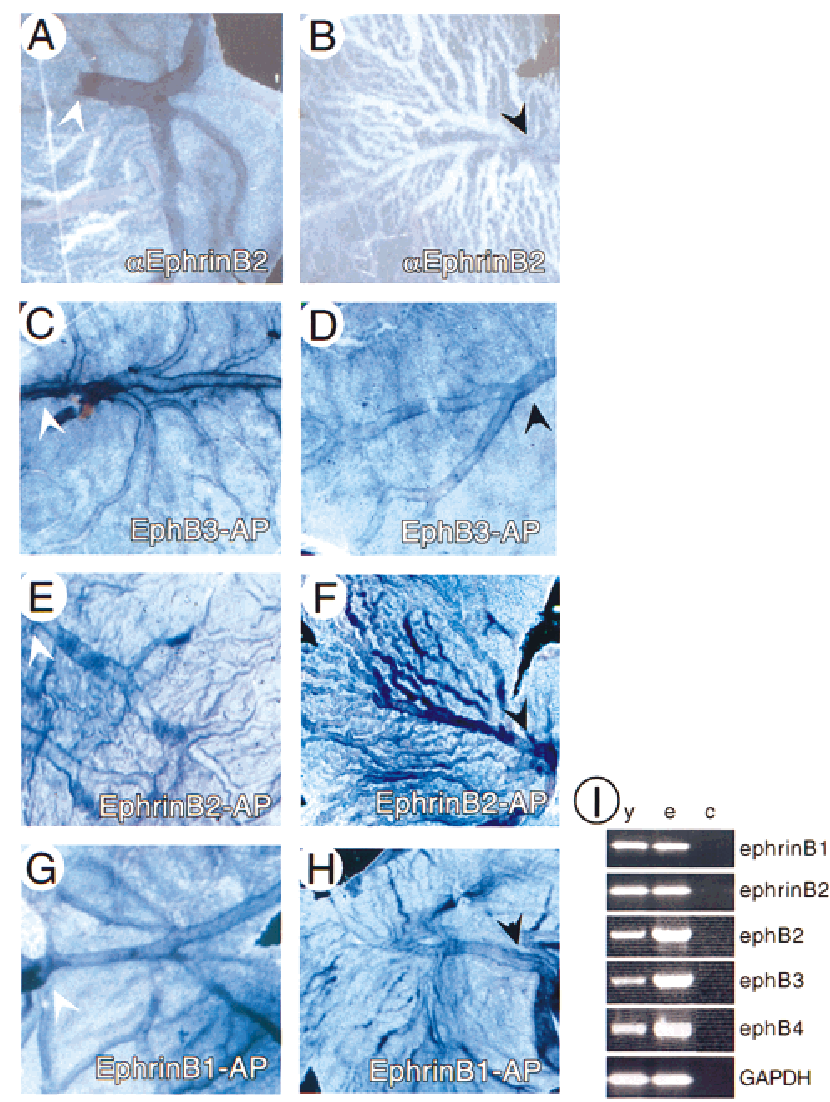

Figure 1. Expression of ephrinB ligands and EphB receptors in yolk sac blood vessels. Whole mount stainings of E9.5 yolk sacs with an anti-ephrinB2 antibody $(A, B)$ or with alkaline phosphatase (AP) fusion proteins $(C-H)$. Vitelline arteries were identified as the posterior vascular domain of the yolk sac (white arrowhead in $A, C, E, G)$, vitelline veins as the anterior domain of the yolk sac (black arrowheads in $B, D, F, H)$, respectively. Immunohistochemistry detects expression of ephrinB2 protein on yolk sac arteries $(A)$, but not, or only at very low levels, on the venous domain $(B)$. Arterial expression of ephrinB2 and possibly other ephrinB ligands was confirmed by binding of the EphB3AP fusion protein $(C)$. Weaker staining was observed on vitelline veins, revealing presence of ligands on both domains of the yolk sac vasculature $(D)$. EphrinB2-AP detects receptors on vitelline veins $(F)$, but gives weaker staining on arteries $(E)$. Binding of ephrinB1-AP to all vessel types $(G, H)$. (I) RT-PCR analysis. mRNAs for at least two ligands (ephrinB1 and ephrinB2) and three receptors (ephB2, ephB3,ephB4) were found in E9.5 yolk sac (y) and embryo (e). No PCR products were obtained in control reactions (c) without reverse transcription.

revealed the presence of ephrinB ligands on both arteries and veins (Fig. 1C,D). Next, we assayed for EphB receptor expression using ligand-AP probes. Whereas ephrinB2AP preferentially stained veins (Fig. 1E,F), ephrinB1-AP bound equally well to arteries and veins (Fig. 1G,H), indicating the presence on veins of at least two EphB receptors with different binding preferences for the two ephrinB ligands. RT-PCR analysis confirmed the presence of ephrinB1, ephrinB2, EphB2, EphB3, and EphB4 mRNAs in yolk sacs (Fig. 1I).
Next, we assayed for expression of ephrinB ligands and EphB receptors in E9.5 wild-type embryos by in situ hybridization analysis and AP-fusion protein staining. EphB1 is largely confined to the nervous system, and ephrinB3 and EphB2 are expressed in neuroectoderm and heart (data not shown; Henkemeyer et al. 1996; K. Brückner, J.P. Labrador, P. Scheiffele, A. Herb, P.H. Seeburg, and R. Klein, in prep.); EphB2 was also found in embryonic mesenchyme (see below). Two ephrins, ephrinB1 and ephrinB2, and two EphB receptors, EphB3 and EphB4, were expressed on embryonic blood vessels. EphrinB2 and EphB4 were expressed in complementary patterns; ephrinB2 mRNA was found in arteries, including dorsal aorta and aortic arches (Fig. 2B), whereas EphB4 was expressed on all major veins, including anterior and posterior cardinal, and umbilical veins (Fig. 2F; Wang et al. 1998). In contrast to published data (Wang et al. 1998), $E p h B 3$ was also prominently expressed on all major veins, and, in addition, showed specific expression on aortic arches (Fig. 2E). mRNA expression patterns were independently confirmed by detecting receptor protein through ephrinB2-AP staining of veins and aortic arches (Fig. 2D). As in yolk sacs, ephrinB2 was not the only ligand expressed by embryonic blood vessels. ephrinB1 mRNA was found in all major blood vessel primordia (Fig. 2C). Coexpression of ephrinB1 and ephrinB2 on dorsal aorta and aortic arches was confirmed by radioactive in situ hybridization analysis by use of oligonucleotide probes (K. Brückner, J.P. Labrador, P. Scheiffele, A. Herb, P.H. Seeburg, and R. Klein, in prep.). Sections of wholemount stained embryos revealed that essentially all endothelial cells lining the veins analyzed in our study, including anterior and posterior cardinal and umbilical veins, coexpress ephrinB1 and two receptors, EphB3 and EphB4 (Fig. 2H-J). Similar coexpression of B subclass ligands and receptors was observed in cultured human microvascular endothelial cells and found to be of functional relevance for in vitro angiogenesis (Stein et al. 1998). Thus, our findings demonstrate coexpression of two ephrinB ligands on arteries, coexpression of ephrinB1, ephrinB2, and EphB3 on aortic arches, and coexpression of ephrinB1, EphB3, and EphB4 in veins, suggesting complex cell-to-cell interactions via ephrins and Eph receptors on endothelial cells in many vascular structures.

\section{Expression of ephrins and Eph receptors at endothelial-mesenchymal interfaces}

During somitogenesis, ephrinB ligands, and EphB2 and EphA4 receptors are expressed in and are partially required for somitogenesis, whereas in parallel regulating neural crest migration and motor axon guidance (Durbin et al. 1998 and references therein). We now show that intersomitic vessels (identified by Flk-1 expression, Fig. 3A) that form at somite boundaries express EphB3 and EphB4 receptors (Fig. 3C,D) at a time when ephrinB2 is expressed in the caudal half of somites (Fig. 3B). Double immunostaining for ephrinB2 and PECAM-1 demonstrates the close contact between ephrinB2-expressing 


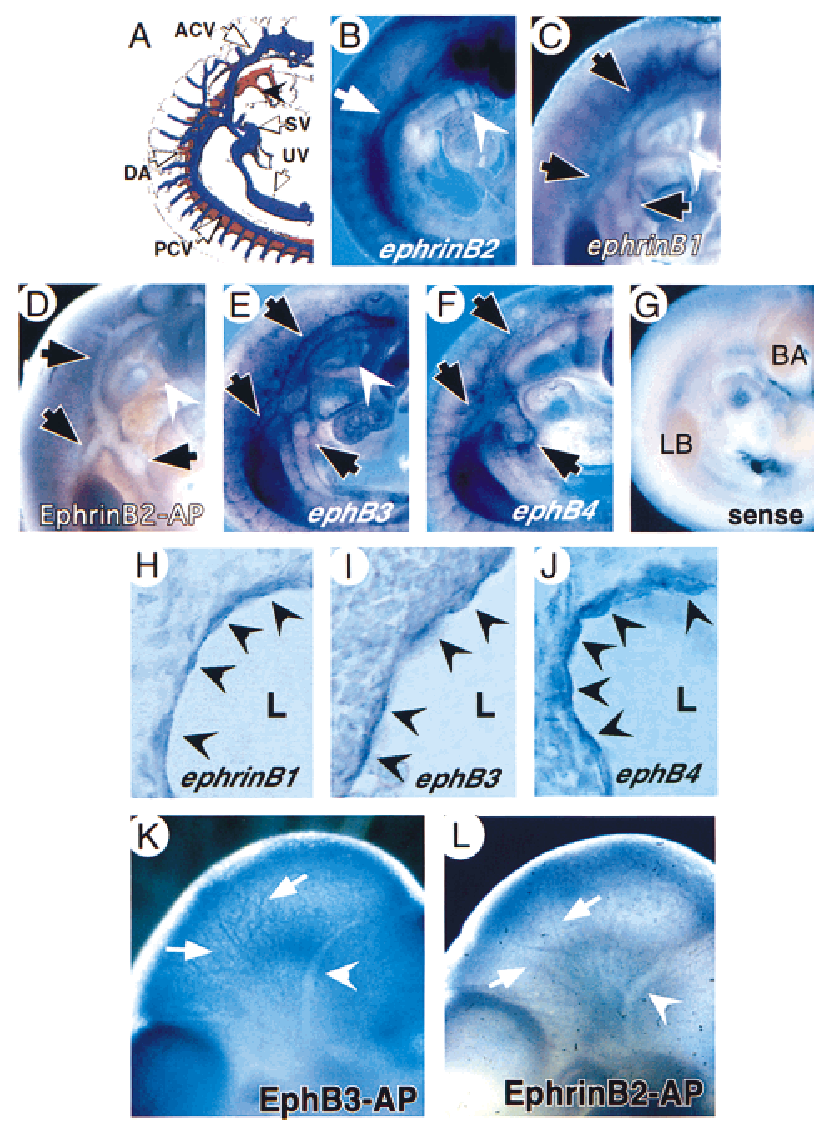

Figure 2. Expression of ephrinB ligands and EphB receptors in embryonic blood vessels. (A) Schematic drawing of the embryonic vasculature with veins in blue and arteries and aortic arches (black arrowheads) in red [modified from Streeter (1918)]. Whole-mount in situ hybridization on E9.5 wild-type embryos with antisense probes as indicated $(B, C, E, F)$ and an $e p h B 4$ sense control $(G)$, anterior is up, dorsal on the left. mRNA for ephrin $B 2(B)$ is expressed in dorsal aorta (white arrow) and aortic arches (white arrowhead), whereas ephrinB1 transcripts $(C)$ are found in all major vessels including dorsal aorta, aortic arches (white arrowhead), cardinal and umbilical veins (black arrows). Receptors binding ephrinB2-AP are localized in cardinal and umbilical veins, and in aortic arches $(D)$. Expression of ephB3 $(E)$ and $e p h B 4(F)$ in anterior and posterior cardinal and tail veins, sinus venosus. ephB3 is also expressed in aortic arches (white arrowhead, $E)$. $(H-J)$ Cross sections of whole-mount in situ hybridized embryos with the indicated antisense probes showing vessel walls of the anterior cardinal vein (approximately the same position for all three embryos). Dorsal is up. Note expression of ephrinB1, ephB3, and ephB4 in all or most endothelial cells (arrowheads). $(K, L)$ AP stainings of E10.5 wild-type embryos. $(K)$ Ligands of EphB3 in head vessels of different diameters including branches of anterior cardinal vein (arrowhead) and capillaries (white arrows). $(L)$ Receptors of ephrinB2 in larger head vessels as well as capillaries. (ACV) anterior cardinal vein; (BA) branchial arches; (DA) dorsal aorta; (LB) limb bud; (SV) sinus venosus; (PCV) posterior cardinal vein; (UV) umbilical vein; (L) vessel lumen.

cells of the dermomyotome with vascular endothelial cells that express EphB receptors (Fig. 3E,F). This suggests a functional interaction between somitic ephrinB2 and endothelial Eph receptors in the morphogenesis of intersomitic vessels and the connecting capillary network. The umbilical vein originating at the sinus venosus near the heart represents another example of possible functional interactions between a mesenchymal EphB receptor and endothelial ephrinB ligands. EphB2 expression, visualized by staining for $\beta$-galactosidase of ephB2lac $Z$ heterozygotes, was found in mesenchymal cells immediately adjacent to the umbilical vein (Fig. 3G), whereas venous endothelial cells, identified by PECAM-1 staining (Fig. 3H), express ephrinB1 and EphB3/ EphB4 receptors (see Fig. 2).

Requirement for ephrinB2 and EphB2/EphB3 receptors in yolk sac and embyonic vascular development

Targeted inactivation of the mouse ephrinB2 gene (Bergemann et al. 1995) (see Materials and Methods) revealed a requirement for ephrinB2 in the formation of
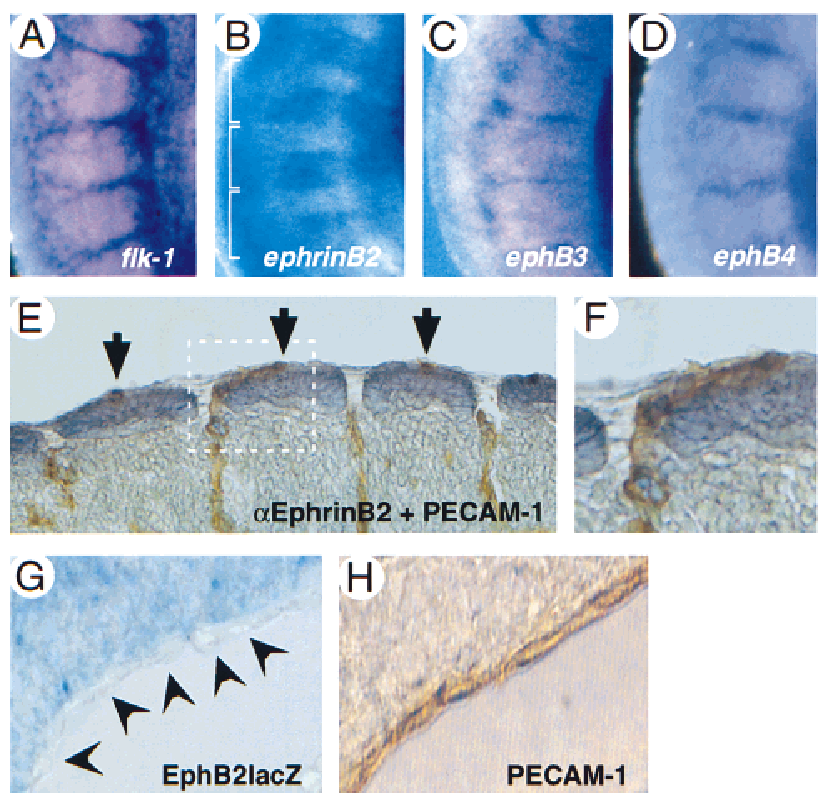

Figure 3. Cell-cell contacts between ligand- and receptor-expressing endothelial and mesenchymal cells. Whole-mount in situ hydrization on E9.5 embryos with antisense probes as indicated. The trunk region is shown, rostral is up, dorsal is left $(A-D)$. Expression of $f 1 k-1(A), e p h B 3(C)$, and ephB4 $(D)$ in intersomitic vessels. $(B)$ ephrinB2 is expressed in the caudal half of somites. Somite boundaries are indicated with a bracket. $(E, F)$ Whole-mount immunohistochemistry on E9.5 wild-type embryos with antibodies against PECAM-1 (brown), staining intersomitic vessels, and ephrinB2 (violet) staining dorsal somites. Tangential section, dorsal is up, rostral is left. A higher magnification of the area indicated by a white box $(E)$ is shown $(F)$. Note that endothelial cells are in direct contact with ephrinB2expressing somitic cells. $(G)$ Cross section through an E10.5 EphB2lacZ mutant heterozygote (Henkemeyer et al. 1996) at the level of the umbilical vein near the sinus venosus, stained for $\beta$-galactosidase activity, dorsal is up. Expression of EphB2 ( $\beta$-gal) can be seen in mesenchymal cells adjacent to unstained endothelial cells of the vessel wall, as identified by PECAM-1 staining $(H)$. 
the embryonic vasculature. ephrinB2 ${ }^{-/-}$mutants at E9.5 and E10 were growth retarded and exhibited an inflated pericardium with a beating heart, but with little, if any, blood flow in the embryo (data not shown). E9.5 wildtype yolk sacs exhibited hierarchically organized vessel architecture with numerous large vitelline vessels, whereas ephrinB2 $2^{-/-}$mutants of the same stage had pale yolk sacs (Fig. 4B) and contained a primitive vascular plexus consisting of a uniformly organized network of small interconnecting vessels (data not shown), much like the recently reported phenotype of ephrinB2/taulacZ mutants (Wang et al. 1998). Our independently generated ephrin $\mathrm{B2}^{-/-}$mutant therefore confirms that ephrinB2 has an essential role in early vascular develop-
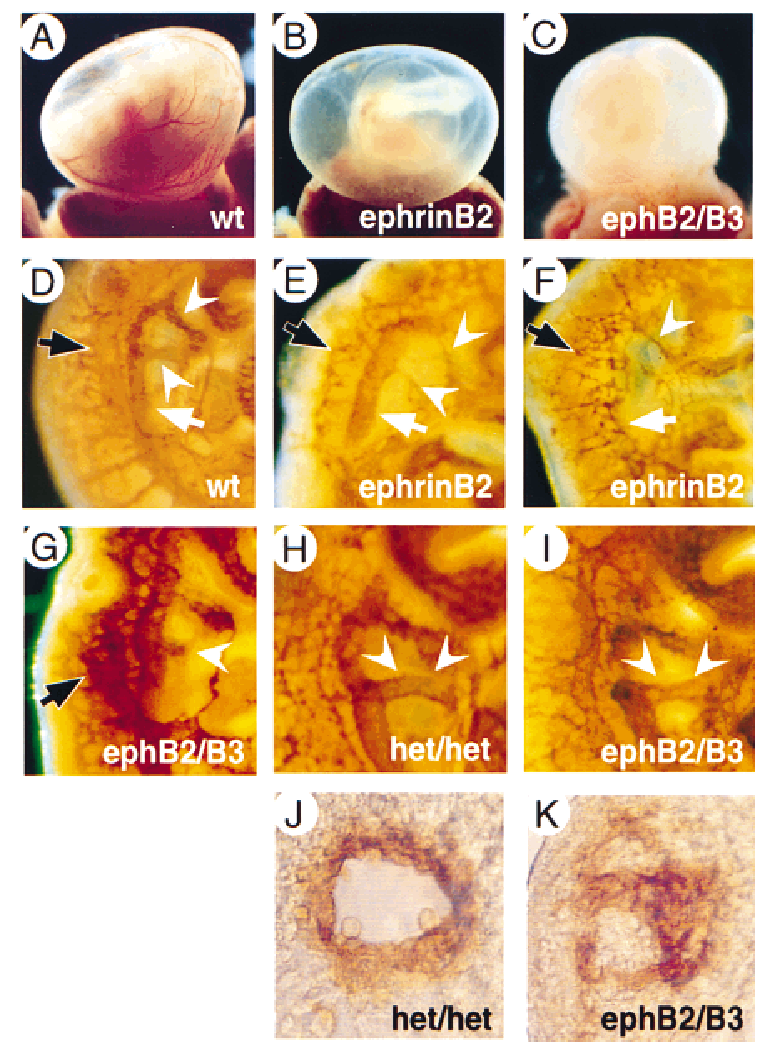

Figure 4. Vascular defects of ephrinB2-/- and ephB2/ephB3 double-mutant embryos. E9.5 yolk sacs of wild-type $(A)$, ephrinB2 $2^{-/}(B)$ and ephB2/ephB3 double-homozygous mutants $(C)$. Lack of major vessel visible in freshly dissected homozygous mutant yolk sacs. $(D-I)$ Whole-mount immunohistochemistry for PECAM-1. Vasculature in the trunk region of E10 embryos stained for PECAM-1, rostral is up, dorsal is left. Appearance of dorsal aorta (white arrow), aortic arches (white arrowheads), and anterior cardinal vein (black arrow) in a wild-type embryo $(D)$ compared with ephrinB2 $2^{-/}$mutants $(E, F)$ and an ephB2/B3 double mutant $(G)$ showing irregular shapes or complete disruption of major vessels. $(H)$ Trunk region of double heterozygous embryo (het/het) showing intact dorsal aorta and fourth aortic arch (white arrowheads). (I) Trunk region of ephB2/ephB3 double-mutant embryo with defective fourth aortic arch and dorsal aorta close to the arch (white arrowheads). (J,K) Cross section through aortic arches of embryos shown in $H$ and $I$, rostral is up. Note that the normal vessel lumen $(J)$ has not formed in the double mutant $(K)$. ment. Moreover, we conclude that ephrinB1 expressed in a partially overlapping domain is unable to compensate for the lack of ephrinB2, suggesting distinct functions of these two ligands in cell-to-cell interactions between embryonic endothelial cells.

The observed expression of EphB2 and EphB3 receptors in yolk sacs, and of EphB2 and EphB3 in embryonic mesenchyme and endothelial cells, respectively, prompted us to examine ephB2/ephB3 double-mutant mice /Orioli et al. 1996) for defects in vascular remodeling. With $30 \%$ penetrance (10 of 32 double mutants), we recovered double-homozygous embryos with vascular defects. These mutants showed pale yolk sacs with few blood vessels (Fig. 4C), were growth retarded compared with their normal littermates and occasionally had extended pericardial sacs (data not shown). No vascular defects were observed in single ephB2 or ephB3 homozygotes, possibly due to very low penetrance. In the embryo, vascular defects were similar, but not identical to those observed in ephrinB2 $2^{-/-}$mutants. In the trunk region, dorsal aorta, aortic arches, and large anterior, cardinal veins are easily recognizable in PECAM-1-stained wild-type embryos (Fig. 4D). Figure 4E shows a representative ephrinB2 $2^{-/-}$mutant embryo, in which the dorsal aorta primordia had formed normally, whereas the fourth aortic arch and anterior cardinal vein were abnormal. In more severe cases of ephrinB2-/- mutants, we observed embryos with one or no dorsal aorta, whereas cardinal veins were always abnormal (Fig. 4F). Severely affected ephB2/ephB3 double homozygotes had abnormally shaped major vessel primordia (Fig. 4G). Less severely affected embryos showed normal dorsal aortas and cardinal veins, but lacked a functional fourth aortic arch that forms the outflow tract of the heart (Fig. 4H,I). Cross sections through this area of the trunk revealed that endothelial cells had failed to organize into a luminar vessel (Fig. 4J,K). Taken together, these data indicate that a significant proportion of embryos require EphB2/EphB3 receptors for proper vascular development. Both ephrinB2-/- and ephB2/ephB3 double mutants show a variable phenotype with respect to the formation of large vessel primordia by vasculogenesis, suggesting the cooperation of other ligands, possibly ephrinB1, and receptors, such as EphB4, in this process.

Defective angiogenesis of head, heart, and intersomitic vessels in ephrinB2 and ephB2/ephB3 mutant embryos

At E10, wild-type embryo heads contained a highly organized vascular system with large diameter branches extending from the anterior cardinal vein (arrowheads in Fig. 5A) and internal carotid artery. In contrast, ephrin $\mathrm{B}^{-/-}$mutants exhibited a primitive vasculature with uniformly sized, poorly organized vessels (Fig. 5B). Likewise, ephB2/ephB3 double homozygotes have fewer, small diameter head vessels (Fig. 5C) or, in severe cases, were arrested at the primary capillary plexus stage (data not shown), indicating that angiogenesis had not occurred or was severely delayed. Whole-mount staining with AP fusion proteins revealed partially overlapping 
Figure 5. Defects in the vasculature of head, heart, and somitic vessels in ephrin $B 2^{-/-}$and $e p h B 2 / e p h B 3$ receptor double mutants. Head region of PECAM-1-wholemount stained E10 embryos $(A-C)$. Branches of anterior cardinal vein of larger diameter are indicated by white arrowheads $(A)$. Note the absence of large diameter vessels in the head of an $e p h B 2 / e p h B 3$ double-mutant embryo $(C)$. In more severe examples of receptor double mutants (data not shown) and in all ephrinB2-/- mutant embryos $(B)$ head vasculature remains organized as a primitive capillary plexus. PECAM-1-stained hearts of wild-type $(D)$, ephrinB2-/- $(E)$, ephB2/ephB3 double mutants $(F)$ at E10. Note smaller size of the heart and reduced trabeculation in ventricle (Ve) in ephrinB2-/- $(E)$ and ephB2/ ephB3 double mutants $(F)$ compared with wild-type heart $(D) .(G, H)$ Sections of PECAM-1-stained hearts of wild-type $(G)$ and ephB2/ephB3 double mutants $(H)$. $(I-M)$
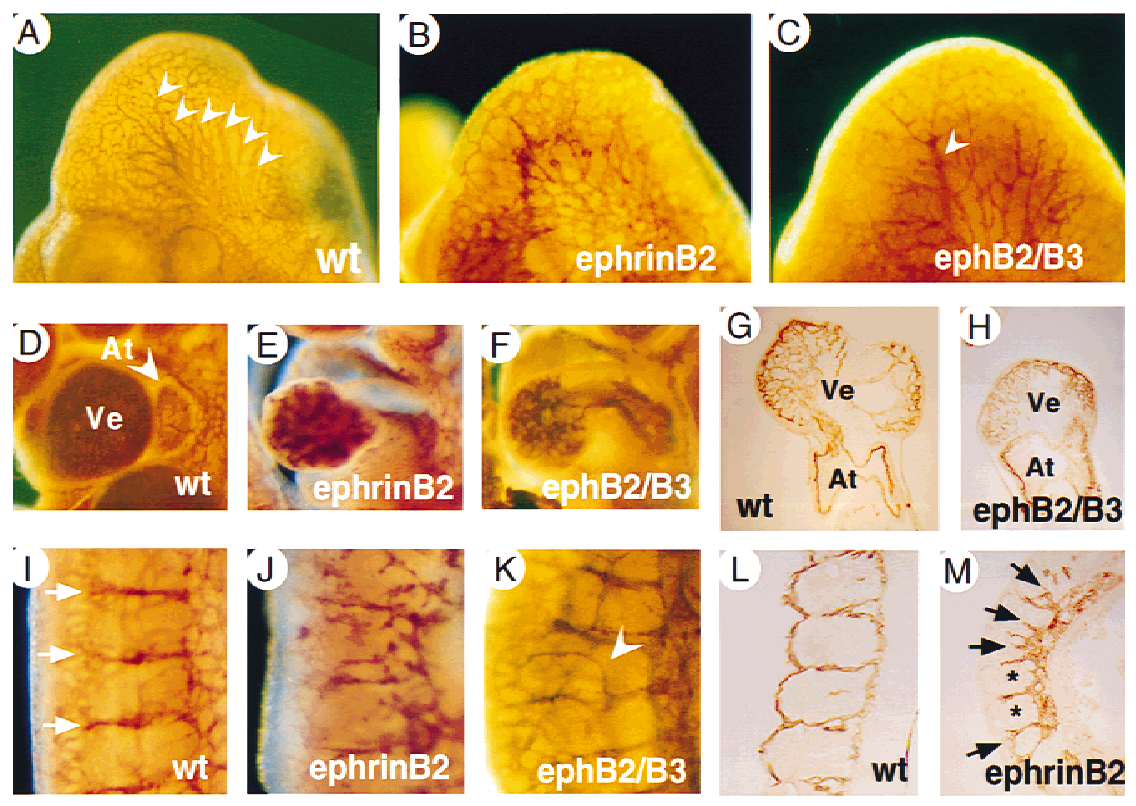

Intersomitic vessels ofthe trunk at lumbar level stained for PECAM-1 (E10). (I) Wild-type embryo showing segmented pattern of intersomitic vessels (white arrows) and capillary network. Severe disorganization of intersomitic vessels and reduced capillary network in ephrinB2 $2^{-/-}$mutants $(J)$. ephB2/ephB3 double mutants show milder defects, e.g., abnormal dorsal sprouts from intersomitic vessels (arrowhead, $K)$. $(L, M)$ Sagittal sections of PECAM-1 stained embryos. $(L)$ Wild-type embryo. $(M)$ ephrinB2 ${ }^{-/-}$embryo showing two somites with normal vessels at somitic borders $\left({ }^{\star}\right)$ and several somites with abnormal sprouts penetrating into somites (black arrows).

expression of ephrinB ligands and EphB receptors in head vessels, including the capillary bed of the head (Fig. 2K,L).

Normal heart ventricles are filled with numerous myocardial trabeculations, finger-like projections of the myocardial wall lined by PECAM-1 positive endocardial cells (Fig. 5D,G). In contrast, ephrinB2-/- and ephB2/ ephB3 mutant hearts were smaller and contained fewer and less intricately folded trabeculae in heart ventricles (Fig. 5E,F,H). This phenotype is reminiscent of that seen in embryos lacking Ang1 (Suri et al. 1996) or its receptor Tie-2 (Sato et al. 1995).

In the trunk region of wild-type embryos, intersomitic vessels are arranged in segments located between somite boundaries. On the dorsal side, they have been remodeled into a highly arborized capillary network (Fig. 5I). In ephrinB2 $2^{-/-}$mutants, intersomitic vessels showed poor organization and they were less branched than their counterparts in wild-type embryos (Fig. 5J). In affected ephB2/ephB3 double homozygotes, intersomitic vessels were present in the normal segmented pattern. However, abnormal dorsal branches were observed (arrowhead in Fig. 5K). Similar abnormal branches within somites were revealed in PECAM-1-stained sections of ephrinB2-/mutants (Fig. 5M, arrows). These results demonstrate a requirement for EphB2 and EphB3 in heart development and in remodeling of the vasculature of head and somites.

\section{EphrinB ligands induce capillary sprouting} in an in vitro sprouting angiogenesis assay

To begin to determine the cellular responses to ephrin signaling in angiogenesis, we used an in vitro sprouting assay that recapitulates some aspects of sprouting angiogenesis in vivo (Risau 1997). This assay involving adrenal-cortex-derived microvascular endothelial (ACE) cells on microcarrier $(\mathrm{MC})$ beads has been used to evaluate the sprouting activity of Ang1 (Koblizek et al. 1998), which is also required for vascular remodeling (Suri et al. 1996). By flow cytometry with ephrinB-IgG fusion proteins (ephrinB-Fc), the presence of receptors for ephrinB1 and ephrinB2 was detected on ACE cells (data not shown). Purified ephrinB1-Fc induced a highly significant increase in the number of sprouts with a length exceeding the diameter of the bead (Fig. 6). The sprouting activity of ephrinB1 was completely blocked with Fc fusions of two of the cognate receptors, EphB1 and EphB2 (Gale et al. 1996) (Fig. 6D). No inhibition was observed in the presence of EphA5-Fc, a member of the A subclass of Eph receptors that does not bind to ephrinB1. Similar sprouting activity was associated with ephrinB2-Fc. Interestingly, in this case, the ligand was only effective when presented in a preclustered form (Fig. 6E). These results suggest that ephrinB1 and ephrinB2 have stimulatory influences on capillary sprouting that may be qualitatively different depending on their degree of clustering, a fact that may be relevant for their in vivo functions.

As presented above, the vascular phenotype of ephrinB2 and EphB2/B3 mutants bear a striking resemblance to previously characterized mouse mutants of the Tie and Ang family of RTKs and ligands (Dumont et al. 1994; Puri et al. 1995; Sato et al. 1995; Suri et al. 1996). Furthermore, our in vitro assay demonstrates very similar cellular responses of endothelial cells to ligands of 

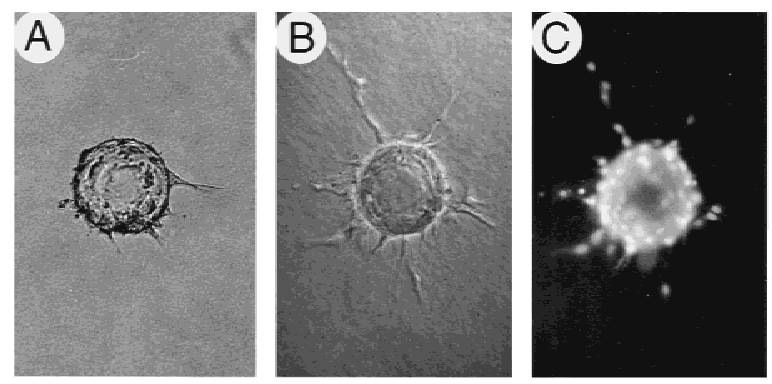

(D)

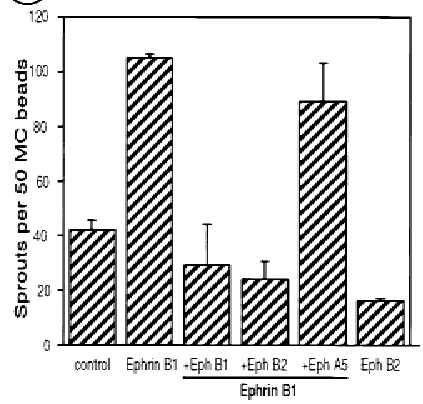

(E)

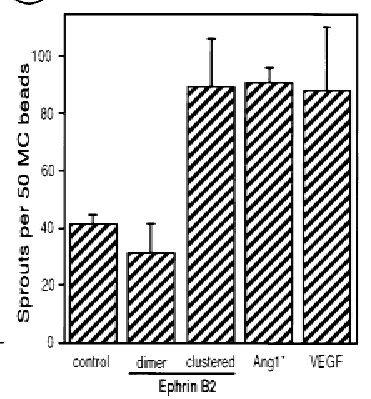

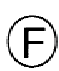

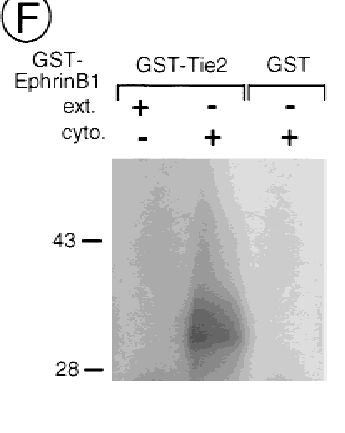

Figure 6. EphrinB ligands induce sprouting angiogenesis in vitro. Adrenal-cortexderived microvascular endothelial (ACE) cells (passage 11) on beads in three-dimensional fibrin gels incubated with control sample $(A)$ or purified ephrinB1-Fc $(B, C)$. $(A, B)$ Phase-contrast photomicrographs. $(C)$ Fluorescent nuclei of endothelial cells stained with Hoechst dye. $(D, E)$ Quantitative analysis of sprout formation expressed as the number of sprouts with lengths exceeding the diameter of the bead per $50 \mathrm{MC}$ beads. (D) EphrinB1-Fc (100 ng/ml) was used unclustered in either absence or presence of $20 \mu \mathrm{g} / \mathrm{ml}$ of the receptors EphB1Fc, EphB2-Fc, or EphA5-Fc. EphB2-Fc alone had no sprouting activity in this assay. (E) EphrinB2-Fc $(74 \mathrm{ng} / \mathrm{ml})$ was used either unclustered or preclustered and compared with saturating amounts of Ang-1 $(670 \mathrm{ng} / \mathrm{ml})$ and VEGF $(25 \mathrm{ng} / \mathrm{ml})$. Values are mean \pm S.E.M. $(n=4)$. $(F)$ Ang1 receptor (Tie-2) phosphorylates the ephrinB1 cytoplasmic domain in vitro. Bacterially produced GST-Tie-2 or GST alone were purified and a fraction $(200 \mathrm{ng}$ ) was combined with $200 \mathrm{ng}$ of either GST-ephrinB1 extracellular domain (ext.) or GST-ephrinB1 cytoplasmic domain (cyto.) and subjected to an in vitro kinase reaction with the use of $\left[\gamma^{32} \mathrm{P}\right] \mathrm{ATP}$. Reaction products were analyzed by $10 \%$ SDS-PAGE, stained with Coomassie brilliant blue (not shown), dried, and exposed to X-ray film. Note that the ephrinB1 cytoplasmic domain, but not ephrinB1 extracellular domain, is a direct in vitro substrate of Tie-2.

both families, thus raising the possibility that these two signaling systems may interact in the mediation of this response. We have recently shown that activated PDGF receptors can rapidly induce ephrinB tyrosine phosphorylation in cis (Brückner et al. 1997). Receptors for Ang1 (Tie-2) and VEGF share structural characteristics with receptors for PDGF including multiple immunoglobulin-like domains in their extracellular region and, importantly, a split kinase domain (Fantl et al. 1993). Therefore, we asked if there was a similar biochemical interaction between Tie- 2 receptors and ephrinB1. In an in vitro kinase assay we observed that bacterially expressed GST-Tie2 is capable of directly phosphorylating the ephrinB1 cytoplasmic domain (Fig. 6F). These results suggest cross talk between the signaling pathways triggered by soluble angiogenic factors and by cell-associated ephrinB proteins.

\section{Discussion}

A recent report by Wang et al. (1998) presented a picture in which ephrinB2 ligands on arteries interact with EphB4 receptors on veins, and this interaction is required and sufficient for early remodeling of the embryonic vasculature. Here we describe a much more complex situation, with two transmembrane ephrinB ligands and three EphB3 receptors expressed in or adjacent to vascular endothelial cells. We demonstrate that two Eph receptors, EphB2 and EphB3, are critically required for the remodeling of the embryonic vasculature. Similar to mice lacking ephrinB2, the angiogenic processes leading to the network of small and large vessels and requiring sprouting from and pruning of existing vessels are disrupted in a fraction of ephB2/ephB3 double mutants. Furthermore, our expression and phenotypic analyses suggest that ephrin-Eph interactions are not restricted to the arterialvenous boundary, but occur throughout most of the vasculature, between endothelial cells and at endothelialmesenchymal contact zones.

\section{Ephrins regulate capillary sprout formation in vitro}

We also provide the first demonstration of a direct response of endothelial cells to ephrins by showing that soluble ephrinB ligands induce sprouting behavior by endothelial cells in vitro with comparable potency to known angiogenic factors such as Ang1 and VEGF. These findings suggest that ephrins have a stimulatory role in capillary sprout formation. Alternatively, ephrinEph signaling may participate in the regulation of contact inhibition of endothelial cells. Exogenously provided ephrinB may relieve cells from contact inhibition, possibly by increasing cell motility, thereby allowing sprouting to occur in this assay. The relatively simple assay gave an unexpectedly complex readout, providing mechanistic insight into ephrin actions on this cell population. Unclustered ephrinB1 was capable of inducing capillary sprouts, whereas only preclustered ephrinB2 showed the same activity. Although it cannot be excluded that a certain level of spontaneous clustering occurred in some preparations of ephrinB1 chimeras in the absence of clustering antibodies, our findings corre- 
late well with published experiments on neurons that showed that unclustered ephrinB1 was active in an in vitro collapse assay. Moreover, ephrinB2-Fc required preclustering to activate EphB4 receptors (Meima et al. 1997). The in vivo correlates of these observations are uncertain. On the one hand, the efficacy of unclustered ephrinB1 in vitro may imply that this ligand is effective in vivo even at low expression levels that preclude presentation of clustered ligand. On the other hand, the requirement for clustered ephrinB2 in vitro may imply that the presentation of ephrinB2 by cells in vivo in clustered and unclustered form, for example, because of different levels of expression or in response to yet-unidentified molecular signals, could promote qualitatively different responses in endothelial cells.

\section{Boundary formation between arterial and venous domains}

The mechanism of ephrinB and Eph receptor function in vivo is unclear. The case is complicated, because (1) several different ligands and receptors are present on endothelial cells and adjacent structures in at least partially overlapping expression patterns (this report; Pandey et al. 1995), (2) ephrinB ligands exhibit largely promiscuous binding to the various EphB receptors (Flanagan and Vanderhaeghen 1998), (3) active ligand-receptor complexes require higher order ephrin clusters (this report; Davis et al. 1994; Gale and Yancopoulos 1997; Stein et al. 1998), (4) ephrinB ligands and EphB receptors have the capability to signal bidirectionally (Holland et al. 1996; Brückner et al. 1997). On the basis of the complementary expression of ephrinB2 on arteries and EphB4 receptors on veins, it has been proposed that bidirectional signaling by these two molecules is crucial for the development of the embryonic vasculature (Wang et al. 1998). By analogy to their known repulsive interactions in the nervous system, it was suggested that ephrinB2-EphB4 interactions may form a boundary between arterial and venous domains that simply prevents cell intermixing (Fig. 7A; Yancopoulos et al. 1998). It was suggested that interaction at the boundary may also prevent the fusion of arterial and venous structures into larger vessels, ensuring that instead they remodel into a capillary network. This model may in part be correct, but requires in vitro data showing repulsive interactions between endothelial cells via ephrin-Eph interactions. Our demonstration of coexpression of ephrinB1, EphB3, and EphB4 in veins argues for more complex interactions. A model based on repulsion would require signaling events mediated by the interaction of ephrinB2 with EphB4 that are distinct from interactions with coexpressed ephrinB1 and EphB3.

\section{Ephrin-Eph interactions during vascular morphogenesis}

Our in situ hybridization analysis and AP whole-mount stainings, as well as previously published in vitro obser-

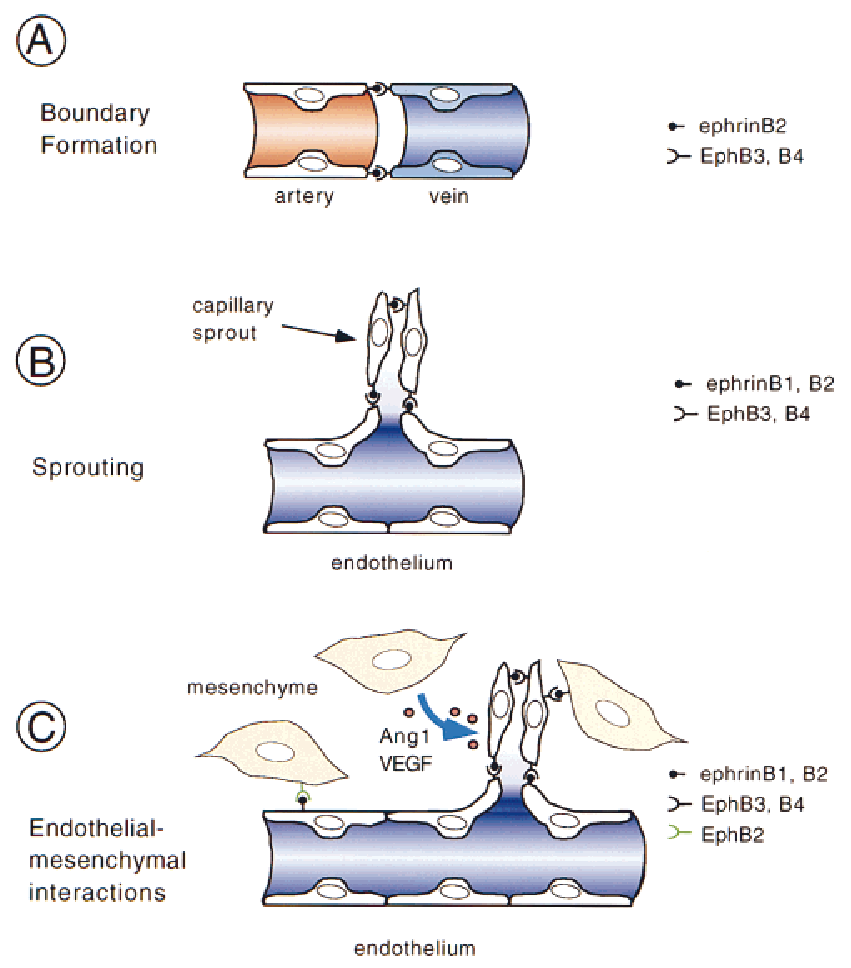

Figure 7. Presumed mechanisms and sites of action of ephrins and Eph receptors during remodeling of the vasculature. $(A)$ Interaction of ephrinB2 ligand expressed on arteries and EphB3 and EphB4 receptors expressed on veins demarcates the boundary between arterial and venous domains. By analogy to the action in the nervous system, it was suggested that ephrin-Eph interactions may prevent intermixing of arterial and venous endothelial cells and, following sprouting, may result in the formation of a capillary network (Yancopoulos et al. 1998). However, this model was based on the exclusive and complementary expression of ephrinB2 and EphB4. (B) Coexpression of ligands and receptors on the same type of vessels (e.g., veins) provides a cell-to-cell signal for endothelial cells that may rather be stimulatory and help to promote morphogenesis and sprouting. $(C)$ Mesenchymal cells adjacent to blood vessels also express ephrins or Eph receptors and may help patterning the vasculature. In the somites, this signal may be inhibitory and prevent sprouting, whereas in other regions, stimulatory signals are conceivable. Mesenchymal cells are also the source of angiogenic factors such as Ang1 and VEGF, which may modulate ephrinBEphB receptor signaling.

vations (Stein et al. 1998) indicate that endothelial cells can coexpress ephrin ligands and their cognate Eph receptors, suggesting that ephrin-Eph signaling participates in endothelial cell-to-cell communication. The observed defects in aortic arches of ephrinB2 $2^{-/-}$and ephB2/ ephB3 double mutant embryos suggest such interactions between ephrinB2, EphB3, and possibly ephrinB1 on endothelial cells. Coexpression and interaction of ephrinB1, EphB3, and EphB4 on major vein primordia may be required for remodeling of venous structures. We suggest that cell-to-cell interactions between endothelial cells of the same vessel type via the ephrin/Eph system result in stimulatory signals that promote endothelial 
morphogenesis and sprouting, eventually resulting in formation of functional vessels (Fig. 7B). The signaling events triggered in this process may be qualitatively different from signaling that occurs at the arterial-venous boundary. Ligand clustering and unidirectional versus bidirectional signaling could provide the molecular bases for this difference in signaling.

\section{Interactions between endothelial and mesenchymal cells}

An additional potential site of ephrin-Eph interaction is at the endothelial-mesenchymal interface (Fig. 7C). We observed mesenchymal cells of the dermomyotome expressing ephrinB2 to be in close contact with intersomitic vessels that express EphB3 and EphB4 receptors. This expression is of functional relevance for vascular remodeling, because it is correlated with a reduction of the intersomitic capillary bed of ephrinB2-/- and ephB2/ $e p h B 3$ double mutants. Moreover, during somitogenesis, ephrinB2 is expressed in the caudal half of the somites (see Fig. 3B; Wang and Anderson 1997) and may participate in the segmental organization of intersomitic vessels. Consistent with this hypothesis, we found defective segmental arrangement of intersomitic vessels in ephrinB2 $2^{-/-}$mutants and abnormal sprouts penetrating the somites in ephB2/ephB3 mutants. On the basis of these phenotypes, we speculate that the nature of the interaction of somitic ephrinB2 with endothelial $\mathrm{EphB}$ receptors may be to suppress sprouts, which are therefore seen in the mutants. Consequently, EphB3 and EphB4 receptors would have cell autonomous functions in this structure, whereas mesenchymal ephrinB2 may function as a ligand for these receptors. The reciprocal situation was observed in the umbilical vein, in which EphB2-expressing mesenchymal cells were in close contact with PECAM-1 positive endothelial cells expressing the ligand ephrinB1. Although we did not find any obvious defects in this structure in ephB2/ephB3 mutant homozygotes, perhaps because of functional redundancy with other $\mathrm{EphB}$ receptors or the result of low penetrance, we speculate that Eph receptors expressed by cells adjacent to endothelial cells may serve as ligands for endothelial ephrins, which would engage in reverse signaling much the same as has been proposed for anterior commissure neurons (Henkemeyer et al. 1996; Orioli et al. 1996).

Mesenchymal cells are also the source of angiogenic factors such as VEGF and Ang1, the latter being required for remodeling of the embryonic vasculature. How might these two signaling systems interact in the developing vasculature? EphrinB-EphB interactions may regulate the expression of Ang1 or its receptors Tie-2 and Tie-1. However, our preliminary RT-PCR expression analysis indicates the presence of Ang1, Tie-2, and Tie-1 mRNA transcripts in ephrinB2 $2^{-/-}$mutants (data not shown). Alternatively, Ang1 and VEGF may regulate ephrinB-EphB signaling. Consistent with this hypothesis, we show that Tie-2 can directly phosphorylate the cytoplasmic domain of ephrinB2 at least in vitro. Although in vivo data are not yet available, it is possible that one of the actions of Ang1 is to activate ephrin-Eph signaling by inducing tyrosine phosphorylation and reverse signaling by ephrins. Whatever the mechanism, we suggest that mesenchymal cells interact with endothelial cells both through secreted factors and by cell-to-cell signaling via the ephrinB-EphB system (Fig. 7C).

\section{Angiogenesis in the nervous system}

Vascular development of the nervous system involves angiogenic sprouting from adjacent vessels into neuroectodermal tissue and may be mediated by similar mechanisms such as endothelial-mesenchymal interactions. Interestingly, angiogenic sprouting into the ner-

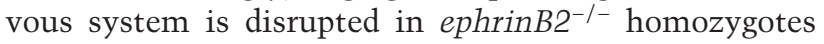
(data not shown; Wang et al. 1998). Those workers suggested that ephrinB2 ligand signaling was required in arterial endothelial cells after interaction with EphB2-expressing cells in the neural tube. However, we did not observe defects in neural tube vascularization in ephB2/ ephB3 double knockout embryos (data not shown). This may be due to overlapping expression and functional compensation by other EphB receptors such as EphB1 in the nervous system. Alternatively, it is possible that ephrinB2 expressed at various levels of the neural tube provides a sprout-inducing signal to EphB3/EphB4-expressing venous endothelial cells, thereby stimulating capillary ingrowth into the neural tube. Analysis of conditional mutant mice lacking ephrinB ligands in the nervous system will hopefully clarify this issue.

\section{Signaling events induced by ephrin-Eph interactions}

Some evidence suggests that the vascular phenotype observed in the two classes of mutant embryos presented here is at least in part due to interference with EphB receptor signaling. Our in vitro data show an induction of sprouting by soluble (clustered) ephrins, demonstrating a direct role of EphB receptors in mediating this response, which mimics some aspects of vascular remodeling in vivo. Activated $\mathrm{EphB}$ receptors are known to bind to the Ras GTPase activating protein, RasGAP (Holland et al. 1997), which in turn recruits other signaling molecules that may eventually mediate cellular responses such as changes in actin polymerization and cell shape (Brückner and Klein 1998). Interestingly, mice lacking RasGAP show vascular remodeling defects similiar to the phenotypes of the mice described here (Henkemeyer et al. 1995), raising the possibility that RasGAP mediates EphB receptor signaling in endothelial cells.

Reverse signaling by ephrinB ligands may also contribute to the phenotype of the mice described here. The vascular remodeling deficit observed in ephB2/ephB3 double-mutant mice must at least partially reflect outside-in signaling into endothelial cells, because EphB2 expression is not observed on vessels. Functional redundancy between mesenchymal EphB2 and endothelial EphB3 receptors may be due to interaction with endo- 
thelial ephrinB1, whose main function may be that of a receptor. Little is known about signaling events downstream of ephrins. Activated ephrinB ligands are phosphorylated on tyrosine, thus, initiating phosphotyrosinemediated signaling, and at the same time are inhibitory for signaling by activated receptor tyrosine kinases expressed in the same cell (Brückner et al. 1997). This suggests that ephrinB signaling in endothelial cells could participate in cross talk with the many receptor tyrosine kinases known to be essential for vasculogenesis and angiogenesis (Risau 1997).

\section{Future directions}

Ephrins and Eph receptors have been found to be expressed on a variety of solid tumors and in tumor cell lines (Brambilla and Klein 1995). Our observations that null mutations in these gene families result in defects in vascular remodeling raise the possibility that blocking ephrin-Eph receptor interaction could interfere with neovascularization of tumor tissue and consequently tumor growth. Conditional mutants lacking ephrins or Eph receptors in adulthood may be important tools to demonstrate a requirement for these molecules in pathological angiogenesis.

\section{Materials and methods}

\section{Targeting vector and generation of mutant mice}

The replacement-type targeting vector pRA62 consisted of 11.7 $\mathrm{kb}$ of ephrinB2 genomic sequences $(10.5 \mathrm{~kb}$ in the long arm and $1.2 \mathrm{~kb}$ in the short arm), a PGK driven neo cassette flanked by loxP sites and a lac $Z$ gene fused to the transmembrane domain of mouse $t r k B$ [pJP68; position 422-460 in the $\operatorname{trk} B$ cDNA (Klein et al. 1989)], inserted 5 amino acids downstream of the presumptive signal peptide of ephrinB2 [nucleotide position 87 in the mouse ephrinB2 cDNA (Bergemann et al. 1995)]. Cell culture, electroporation of R1 ES cells, selection with G418, and blastocyst injections were carried out according to standard protocols. RT-PCR analysis was performed on early embryos and confirmed the absence of ephrinB2 mRNA in ephrinB2 ${ }^{-/-}$mutants (data not shown). Heterozygous offspring showed no overt phenotype, but no ephrinB2-/- mutants were born following intercrosses of heterozygous females and males, indicating a recessive lethal phenotype. The number of heterozygotes born was reduced by half (data not shown) suggesting a dose-dependent embryonic requirement for ephrinB2. Mutant phenotypes were analyzed with essentially the same results in $129 /$ svev $\times$ C57Bl/ 6 and $129 /$ svev $\times$ CD1 mixed genetic backgrounds. EphB2 (Nuk) and EphB3 (Sek4) mutant mice have been described (Henkemeyer et al. 1996; Orioli et al. 1996). The described defects were observed in ephB2 $2^{\text {null/lacZ }} ; e p h B 3^{-/-}$mutants in a $\mathrm{C} 57 \mathrm{Bl} / 6$ background.

\section{RT-PCR analysis}

mRNA was extracted from wild-type yolk sacs and embryos by standard procedures and subjected to reverse transcription with oligo $(\mathrm{dT})_{15}$ primers and PCR amplification. To detect expression of various ephrin/eph genes, the following primer pairs were used: ephrinB2, 5'-CTGTGCCAGACCAGACCAAGA-3' (sense), 5'-CAGCAGAACTTGCATCTTGTC-3' (anti- sense); ephrin-B1，5'-AAGCCACACCAGGAAATCCGC-3' (sense), 5'-CGGTGCCCGCTGTACCACTAC-3' (antisense); ephB2, 5' -ATGCCCTTCTCCACCCTCTCC-3' (sense), 5'-TCTCCTAGTTATGAGTTCTAC-3' (antisense); ephB3, 5'-GCTGGTGAGTTTGGGGAAGTG-3' (sense), 5' -GTGACCCCAATCCTTAGCAG-3' (antisense); ephB4, 5'-CAGGTGGTCAGCGCTCTGGAC-3' (sense), 5'-ATCTGCCACGGTGGTGAGTCC-3' (antisense).

\section{Whole-mount immunohistochemistry}

Wild-type and mutant embryos were isolated, fixed, and stained with a rat antibody against PECAM-1 (Pharmingen 1:100 dilution) and secondary antibodies against rat IgG, and avidin-conjugated peroxidase (Vector) according to published protocols. For double immunohistochemistry, embryos were fixed, bleached with $5 \% \mathrm{H}_{2} \mathrm{O}_{2}$ in methanol for $5 \mathrm{hr}$, blocked with $3 \%$ instant skim milk powder, $0.1 \%$ Triton X-100 in PBS for $2 \mathrm{hr}$, and simultaneously incubated with primary antibodies against PECAM-1 (Pharmingen, 1:100) and ephrinB2 (Santa Cruz, 1:50) in blocking solution at $4^{\circ} \mathrm{C}$ overnight. After extensive washes in blocking solution, embryos were again fixed in $4 \%$ paraformaldehyde for $2 \mathrm{hr}$, washed in PBS, and incubated at $65^{\circ} \mathrm{C}$ for 30 min to inactivate endogenous phosphatases. An additional blocking for $2 \mathrm{hr}$ was then followed by incubation with secondary antibodies (biotinylated anti-rat IgG, Vector, 1:100; antirabbit IgG alkaline phosphatase conjugated, Sigma, 1:100) as before. Finally, embryos were extensively washed, stained by alkaline phosphatase reaction, incubated with avidin-conjugated peroxidase (Vector) overnight, again washed in blocking buffer, and developed in 3,3'-diaminobenzidinetetrahydrochloride (DAB).

Whole-mount staining with alkaline phosphate fusion proteins

Embryos and yolk sacs of wild-type embryos (CD1) were dissected, treated with Dent's fixative (20\% DMSO, 80\% methanol) for $30 \mathrm{~min}$ at room temperature, washed three times with PBS (5 min each), and incubated with fusion proteins (10 nM) of Eph receptors or ephrins and human-secreted alkaline phosphatase (Brambilla et al. 1995) in DMEM, 10\% calf serum, 0.1\% $\mathrm{NaN}_{3}$. Washing, heat inactivation of phosphatases, and color development was performed as described previously (Cheng and Flanagan 1994).

\section{Whole-mount in situ hybridization}

In situ hybridizations were performed as described (Haramis et al. 1995) with unbleached E9.5 embryos treated with proteinase $\mathrm{K}$ for $15 \mathrm{~min}$. Probes were used as follows: Flk-1 (Millauer et al. 1993); ephrinB1, a 1.1-kb fragment corresponding to the fulllength coding region (Bouillet et al. 1995); ephrinB2, a 890-bp fragment extending from nucleotide 4 to 894 (Bergemann et al. 1995); ephB3 (Orioli et al. 1996); ephB4, a 1146-bp fragment extending from nucleotide 104 to 1250 (Ciossek et al. 1995); lac $Z$, a 2.2 -kb fragment encoding the carboxy-terminal 790 amino acids of $\beta$ galactosidase.

\section{In vitro sprouting angiogenesis assay}

The assay and generation of Ang1 * was described (Koblizek et al. 1998). Purifed Fc fusion proteins were described previously 
(Davis et al. 1994; Gale et al. 1996). Clustering of ephrinB2-Fc was done as described (Wang and Anderson 1997).

\section{In vitro kinase assay}

Fusion proteins of GST and mouse Tie2 cytoplasmic domain (GST-Tie2), human ephrinB1 (GST-ephrinB1) extracellular or cytoplasmic domain were expressed in bacterial strain XL1-blue and purified according to standard protocols. GST-Tie2 or GST (200-300 ng) control were incubated together with similiar amounts of GST-ephrinB1 substrates in 20 mM HEPES (pH 7.2), $10 \mathrm{~mm} \mathrm{MnCl}_{2}, 1 \mathrm{~mm} \mathrm{DTT}, 5 \mu \mathrm{M}$ ATP, $185 \mathrm{kBq}\left[\gamma^{-32} \mathrm{P}\right] \mathrm{ATP}$ (Amersham), $100 \mathrm{~nm}$ sodium orthovanadate, $1 \times$ complete protease inhibitor cocktail (Boehringer Mannheim) for $20 \mathrm{~min}$ at $37^{\circ} \mathrm{C}$. After separation of proteins by electrophoresis in a $10 \%$ SDS-polyacrylamide gel, the vacuum-dried gel was exposed to X-ray film (Kodak X-OMAT AR) for $36 \mathrm{hr}$.

\section{Acknowledgments}

We thank A. Plück-Becklas and coworkers of the European Molecular Biology Laboratory Transgenic Core Facility for the generation of chimeric mice, the staff of the animal house for expert support, K. McNagny, S. Adams, and M. Schorpp-Kistner for help in the initial characterization of the phenotype, G. Yancopoulos for suggesting in vitro sprouting assays. Purified recombinant VEGF was a gift from $M$. Clauss. We are thankful to T. Graf and K. Kullander for critically reading the manuscript. Support for this study came in part from the Deutsche Forschungsgemeinschaft (DFG, K1948/2-1), from the Human Frontier Science Program Organization, from a European Union Biotechnology network grant to R.K, and from the Deutsche Krebshilfe and the Max Planck Society to C.W., U.D., and W.R. R.H.A. was supported by an European Molecular Biology Organization postdoctoral fellowship.

The publication costs of this article were defrayed in part by payment of page charges. This article must therefore be hereby marked 'advertisement' in accordance with 18 USC section 1734 solely to indicate this fact.

\section{References}

Bergemann, A.D., H.-J. Cheng, R. Brambilla, R. Klein, and J.G. Flanagan. 1995. Elf-2, a new member of the Eph ligand family, is segmentally expressed in mouse embryos in the region of the hindbrain and newly forming somites. Mol. Cell. Biol. 15: 4921-4929.

Bouillet, P., M. Oulad-Abdelghani, S. Vicaire, J.-M. Garnier, B. Schuhbaur, P. Dolle, and P. Chambon. 1995. Efficient cloning of cDNAs of retinoic acid-responsive genes in P19 embryonal carcinoma cells and characterization of a novel mouse gene, Stra1 (mouse Lerk2/Eplg2). Dev. Biol. 170: 420433.

Brambilla, R. and R. Klein. 1995. Telling axons where to grow: A role for Eph receptor tyrosine kinases in guidance. Mol. Cell. Neurosci. 6: 487-495.

Brambilla, R., A. Schnapp, F. Casagranda, J.P. Labrador, A.D. Bergemann, J.G. Flanagan, E.B. Pasquale, and R. Klein. 1995. Membrane-bound LERK2 ligand can signal through three different Eph-related receptor tyrosine kinases. EMBO $\mathrm{I}$. 14: 3116-3126.

Brennan, C., B. Monschau, R. Lindberg, B. Guthrie, U. Drescher, F. Bonhoeffer, and N. Holder. 1997. Two Eph receptor tyrosine kinase ligands control axon growth and may be involved in the creation of the retinotectal map in the zebrafish. Development 124: 655-664.

Brückner, K. and R. Klein. 1998. Signaling by Eph receptors and their ephrin ligands. Curr. Opin. Neurobiol. 8: 375-382.

Brückner, K., E.B. Pasquale, and R. Klein. 1997. Tyrosine phosphorylation of transmembrane ligands for Eph receptors. Science 275: 1640-1643.

Carmeliet, P., V. Ferreira, G. Breier, S. Pollefeyt, L. Kieckens, M. Gertsenstein, M. Fahrig, A. Vandenhoeck, K. Harpal, C. Eberhardt et al. 1996. Abnormal blood vessel development and lethality in embryos lacking a single VEGF allele. Nature 380: 435-439.

Cheng, H.-J. and J.G. Flanagan. 1994. Identification and cloning of ELF-1, a developmentally expressed ligand for the Mek4 and Sek receptor tyrosine kinases. Cell 79: 157-168.

Cheng, H.-J., M. Nakamoto, A.D. Bergemann, and J.G. Flanagan. 1995. Complementary gradients in expression and binding of Elf1 and Mek4 in development of the topographic retinotectal projection map. Cell 82: 371-381.

Ciossek, T., M.M. Lerch, and A. Ullrich. 1995. Cloning, characterization, and differential expression of MDK2 and MDK5, two novel receptor tyrosine kinases of the eck/eph family. Oncogene 11: 2085-2095.

Davis, S., N.W. Gale, T.H. Aldrich, P.C. Maisonpierre, V. Lhotak, T. Pawson, M. Goldfarb, and G.D. Yancopoulos. 1994. Ligands for EPH-related receptor tyrosine kinases that require membrane attachment or clustering for activity. Science 266: 816-819.

Drescher, U., C. Kremoser, C. Handwerker, J. Löschinger, M. Noda, and F. Bonhoeffer. 1995. In vitro guidance of retinal ganglion cell axons by RAGS, a $25 \mathrm{kDa}$ tectal protein related to ligands for Eph receptor tyrosine kinases. Cell 82: 359370.

Dumont, D., J.G. Gradwohl, G.-H. Fong, M. Puri, M. Gertsenstein, A. Auerbach, and M.L. Breitman. 1994. Dominantnegative and targeted null mutations in the endothelial receptor tyrosine kinase, tek, reveal a critical role in vasculogenesis of the embryo. Genes \& Dev. 8: 1897-1909.

Durbin, L., C. Brennan, K. Shiomi, J. Cooke, A. Barrios, S. Shanmugalingam, B. Guthrie, R. Lindberg, and N. Holder. 1998. Eph signaling is required for segmentation and differentiation of the somites. Genes \& Dev. 12: 3096-3109.

Fantl, W.J., D.E. Johnson, and L.T. Williams. 1993. Signaling by receptor tyrosine kinases. Annu. Rev. Biochem. 62: 453-481.

Ferrara, N., K. Carver-Moore, H. Chen, M. Dowd, L. Lu, K.S O'Shea, L. Powell-Braxton, K.J. Hillan, and M.W. Moore. 1996. Heterozygous embryonic lethality induced by targeted inactivation of the VEGF gene. Nature 380: 439-442.

Flanagan, J.G. and P. Vanderhaeghen. 1998. The ephrins and Eph receptors in neural development. Annu. Rev. Neurosci. 21: 309-345.

Fong, G.-H., J. Rossane, M. Gertsenstein, and M.L. Breitman. 1995. Role of the Flt-receptor tyrosine kinase in regulating the assembly of vascular endothelium. Nature 376: 66-70.

Frisen, J., P.A. Yates, T. McLaughlin, G.C. Friedman, D.D. O'Leary, and M. Barbacid. 1998. Ephrin-A5 (AL-1/RAGS) is essential for proper retinal axon guidance and topographic mapping in the mammalian visual system. Neuron 20: 235243.

Gale, N.W. and G.D. Yancopoulos. 1997. Ephrins and their receptors: A repulsive topic? Cell Tissue Res. 290: 227-242.

Gale, N.W., S.J. Holland, D.M. Valenzuela, A. Flenniken, L. Pan, T.E. Ryan, M. Henkemeyer, K. Strebhardt, H. Hirai, D.G. Wilkinson et al. 1996. Eph receptors and ligands comprise two major specificity subclasses, and are reciprocally compartmentalized during embryogenesis. Neuron 17: 9-19. 
Haramis, A.G., J.M. Brown, and R. Zeller. 1995. The limb deformity mutation disrupts the SHH/FGF-4 feedback loop and regulation of 5' HoxD genes during limb pattern formation. Development 121: 4237-4245.

Henkemeyer, M., D.J. Rossi, D.P. Holmyard, M.C. Puri, G. Mbamalu, K. Harpal, T.S. Shih, T. Jacks, and T. Pawson. 1995. Vascular system defects and neuronal apoptosis in mice lacking Ras GTPase-activating protein. Nature 377: 695-701.

Henkemeyer, M., D. Orioli, J.T. Henderson, T.M. Saxton, J. Roder, T. Pawson, and R. Klein. 1996. Nuk controls pathfinding of commissural axons in the mammalian central nervous sustem. Cell 86: 35-46.

Holland, S.J., N.W. Gale, G. Mbamalu, G.D. Yancopoulos, M. Henkemeyer, and T. Pawson. 1996. Bidirectional signaling through the EPH-family receptor Nuk and its transmembrane ligands. Nature 383: 722-725.

Holland, S.J., N.W. Gale, G.D. Gish, R.A. Roth, Z. Songyang, L.C. Cantley, M. Henkemeyer, G.D. Yancopoulos, and T. Pawson. 1997. Juxtamembrane tyrosine residues couple the Eph family receptor EphB2/Nuk to specific SH2 domain proteins in neuronal cells. EMBO J. 16: 3877-3888.

Klein, R., L.F. Parada, F. Coulier, and M. Barbacid. 1989. trkB, a novel tyrosine protein kinase receptor expressed during mouse neural development. EMBO I. 8: 3701-3709.

Koblizek, T.I., C. Weiss, G.D. Yancopoulos, U. Deutsch, and W. Risau. 1998. Angiopoietin-1 induces sprouting angiogenesis in vitro. Curr. Biol. 8: 529-532.

Krull, C.E., R. Lansford, N.W. Gale, A. Collazo, C. Marcelle, G.D. Yancopoulos, S.E. Fraser, and M. Bronner-Fraser. 1997. Interactions of Eph-related receptors and ligands confer rostrocaudal pattern to trunk neural crest migration. Curr. Biol. 7: 571-580.

Meima, L., P. Moran, W. Matthews, and I.W. Caras. 1997. Lerk2 (ephrinB1) is a collapsing factor for a subset of cortical growth cones and acts by a mechanism different from AL-1 (ephrinA5). Mol. Cell. Neurosci. 9: 314-328.

Millauer, B., S. Wizigmann-Voos, H. Schnurch, R. Martinez, N.P. Moller, W. Risau, and A. Ullrich. 1993. High affinity VEGF binding and developmental expression suggest Flk-1 as a major regulator of vasculogenesis and angiogenesis. Cell 72: 835-846.

Nakamoto, M., H.-J. Cheng, G.C. Friedman, T. McLaughlin, M.J. Hansen, C.H. Yoon, D.D.M. O'Leary, and J.G. Flanagan. 1996. Topographically specific effects of Elf-1 on retinal axon guidance in vitro and retinal axon mapping in vivo. Cell 86: $755-766$.

Orioli, D., M. Henkemeyer, G. Lemke, R. Klein, and T. Pawson. 1996. Sek4 and Nuk receptors cooperate in guidance of commissural axons and in palate formation. EMBO J. 15: 60356049.

Orioli, D. and R. Klein. 1997. The Eph receptor family: Axonal guidance by contact repulsion. Trends Genet. 13: 354-359.

Pandey, A., H. Shao, R.M. Marks, P.J. Polverini, and V.M. Dixit. 1995. Role of B61, the ligand for the Eck receptor tyrosine kinase, in TNF- $\alpha$-induced angiogenesis. Science 268: $567-$ 569

Park, S., J. Frisen, and M. Barbacid. 1997. Aberrant axonal projections in mice lacking EphA4 (Eek) tyrosine protein kinase receptors. $E M B O$ J. 16: 3106-3114.

Puri, M.C., J. Rossant, K. Alitalo, A. Bernstein, and J. Partanen. 1995. The receptor tyrosine kinase TIE is required for integrity and survival of vascular endothelial cells. EMBO $\mathrm{I}$. 14: 5884-5891

Risau, W. 1997. Mechanisms of angiogenesis. Nature 386: 671674 .
Risau, W. and I. Flamme. 1995. Vasculogenesis. Annu. Rev. Cell. Dev. Biol. 11: 73-91.

Sato, T.N., Y. Tozawa, U. Deutsch, K. Wolburg-Buchholz, Y. Fujiwara, M. Gendron-Maguire, T. Gridley, H. Wolburg, W. Risau, and Y. Qin. 1995. Distinct roles of the receptor tyrosine kinases Tie-1 and Tie-2 in blood vessel formation. $\mathrm{Na}$ ture 376: 70-74.

Shalaby, F., J. Rossant, T. Yamaguchi, M. Gertsenstein, X.-F. Wu, M.L. Breitman, and A.C. Schuch. 1995. Failure of bloodisland formation and vasculogenesis in Flk-1 deficient mice. Nature 376: 62-66.

Shalaby, F., J. Ho, W.L. Stanford, K.-D. Fischer, A.C. Schuch, L. Schwartz, A. Bernstein, and J. Rossant. 1997. A requirement for Flk1 in primitive and definitive hematopoiesis and vasculogenesis. Cell 89: 981-990.

Smith, A., V. Robinson, K. Patel, and D.G. Wilkinson. 1997. The EphA4 and EphB1 receptor tyrosine kinases and ephrin-B2 ligand regulate targeted migration of branchial neural crest cells. Curr. Biol. 7: 561-570.

Stein, E., A.A. Lane, D.P. Cerretti, H.O. Schoecklmann, A.D. Schroff, R.L. Van Etten, and T.O. Daniel. 1998. Eph receptors discriminate specific ligand oligomers to determine alternative signaling complexes, attachment, and assembly responses. Genes \& Dev. 12: 667-678.

Streeter, G.L. 1918. The developmental alterations in the vascular system of the brain of the human embryo. Contrib. Embryol. 8: 5-38.

Suri, C., P.F. Jones, S. Patan, S. Bartunkowa, P.C. Maisonpierre, S. Davis, T.N. Sato, and G.D. Yancopoulos. 1996. Requisite role of Angiopoietin-1, a ligand for the TIE2 receptor, during embryonic angiogenesis. Cell 87: 1171-1180.

Wang, H.U. and D.J. Anderson. 1997. Eph family transmembrane ligands can mediate repulsive guidance of trunk neural crest migration and motor axon outgrowth. Neuron 18: 383 396.

Wang, H.U., Z.-F. Chen, and D.J. Anderson. 1998. Molecular distinction and angiogenic interaction between embryonic arteries and veins revealed by ephrin-B2 and its receptor EphB4. Cell 93: 741-753.

Xu, Q., G. Alldus, N. Holder, and D.G. Wilkinson. 1995. Expression of truncated Sek1 receptor tyrosine kinase disrupts the segmental restriction of gene expression in the Xenopus and zebrafish hindbrain. Development 121: 4005-4016.

$\mathrm{Xu}$, Q., G. Alldus, R. Macdonald, D.G. Wilkinson, and N. Holder. 1996. Function of the Eph-related kinase rtk1 in patterning of the zebrafish forebrain. Nature 381: 319-322.

Yancopoulos, G.D., M. Klagsbrun, and J. Folkman. 1998. Vasculogenesis, angiogenesis, and growth factors: Ephrins enter the fray at the border. Cell 93: 661-664. 


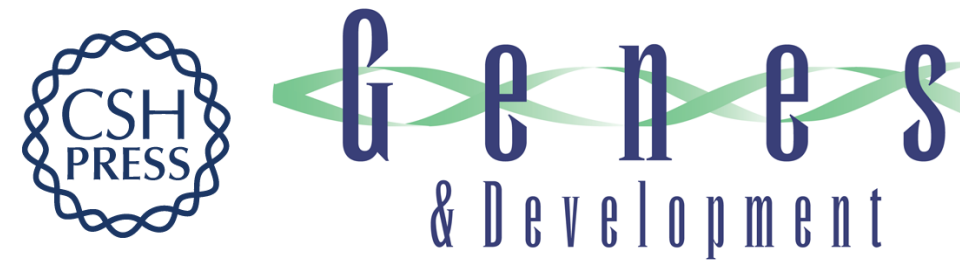

\section{Roles of ephrinB ligands and EphB receptors in cardiovascular development: demarcation of arterial/venous domains, vascular morphogenesis, and sprouting angiogenesis}

Ralf H. Adams, George A. Wilkinson, Cornelia Weiss, et al.

Genes Dev. 1999, 13:

References This article cites 52 articles, 11 of which can be accessed free at: http://genesdev.cshlp.org/content/13/3/295.full.html\#ref-list-1

License

Email Alerting Receive free email alerts when new articles cite this article - sign up in the box at the top Service right corner of the article or click here.

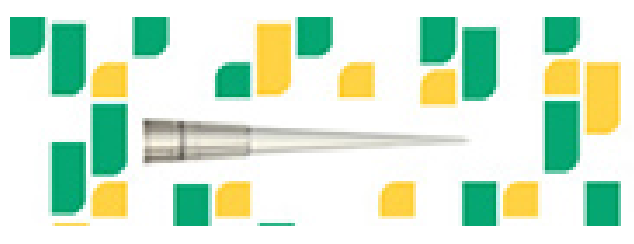

Focused on your science. 